\title{
A Repercussão Geral no Recurso Extraordinário e o direito fundamental de acesso à justiça
}

Lívia Graziela Pini $^{1}$

\begin{abstract}
Resumo
0 presente artigo analisa o instituto da Repercussão Geral no Recurso Extraordinário e sua compatibilidade com o direito fundamental de acesso à justiça. Para isso, inicialmente examina o princípio do acesso à justiça e, posteriormente, analisa sua compatibilidade com 0 novel instituto da repercussão geral no recurso extraordinário. Conclui que é plenamente compatível a coexistência do dito direito fundamental com o novo instituto, em razão de o direito de acesso à justiça não garantir o acesso ao Supremo Tribunal Federal, bem como em razão do caráter relativo dos direitos fundamentais.
\end{abstract}

Palavras-Chave: Repercussão Geral; Recurso Extraordinário; Direitos Fundamentais; Acesso à Justiça.

\section{Introdução}

A Emenda Constitucional n. 45, de 08 de dezembro de 2004, visando efetivar a chamada "Reforma do Judiciário", realizou diversas alterações no texto constitucional. Dentre elas, acresceu o § 3o ao art. 102 da Constituição Federal. Este novo parágrafo trouxe ao jurisdicionado que interpuser recurso extraordinário a necessidade de demonstrar a repercussão geral das questões constitucionais discutidas no caso levado ao Supremo Tribunal Federal.

Contudo, o texto do $\S 3^{\circ}$ enuncia que a forma pela qual essa demonstração deve ser feita será objeto de regulamentação por norma infraconstitucional, o que impossibilitou a aplicação imediata do instituto. Essa regulamentação somente adveio em 20 de dezembro de 2006 com a Lei no 11.418 que inseriu os artigos 543-A e 543-B ao Código de Processo Civil (CPC). A partir desse momento, passou a vigorar no Brasil o instituto da Repercussão Geral no Recurso Extraordinário.

Desde que a Emenda Constitucional enunciou o surgimento deste novo instituto, iniciou-se considerável discussão sobre se a exigência de prévia demonstração da

\footnotetext{
${ }^{1}$ Bacharelando em Direito pela Universidade Estadual de Londrina - UEL
} 
repercussão geral das questões constitucionais do caso concreto como um requisito para a interposição do recurso extraordinário não seria um óbice à efetivação do direito fundamental de acesso à justiça, haja vista que este direito constitui-se em cláusula pétrea constitucionalmente protegida.

A garantia de acesso à justiça, prevista no art. 50, XXXV da Constituição Federal determina que nenhuma lei poderá excluir da apreciação do Poder Judiciário lesão ou ameaça a direito. Portanto, assegura-se a todas as pessoas que busquem o Poder Judiciário para que este se pronuncie acerca de dada violação ou ameaça à direito.

Por outro lado, o instituto da Repercussão Geral impede o acesso ao Supremo Tribunal Federal quando a questão constitucional ventilada no recurso extraordinário não estiver dotada de repercussão geral. Isto porque se o Supremo Tribunal Federal julgar pela ausência da dita repercussão, não analisará o mérito da causa.

Isto posto, surge o seguinte questionamento: 0 instituto da Repercussão Geral, ao impedir que o jurisdicionado tenha seu caso analisado pelo Supremo Tribunal Federal em razão da ausência de repercussão geral, estaria eivado do vício de inconstitucionalidade por violar o direito fundamental do acesso à justiça? É sobre este questionamento que orbitará o presente trabalho.

\section{A Repercussão Geral no Recurso Extraordinário e o direito fundamental de acesso à justiça}

No ordenamento jurídico brasileiro o poder constituinte derivado não tem plena liberdade para alterar a Constituição Federal. Seu poder é limitado por normas previstas pela própria Constituição, que impõe limites temporais ${ }^{2}$, circunstanciais $^{3}$ e materiais. No caso de não observância desses limites a alteração constitucional será viciada e estará sujeita ao sistema de controle de constitucionalidade (AFONSO DA SILVA, 2002, p. 65).

\footnotetext{
${ }^{2}$ Sobre o tema leciona José Afonso da Silva que "as limitações temporais não são comumente encontráveis na história constitucional brasileira. Só a Constituição do Império estabeleceu esse tipo de limitação, visto que previra que tão-só após quatro anos de sua vigência poderia ser reformada" (AFONSO DA SILVA, 2002, p. 66).

${ }^{3} \mathrm{O}$ limite circunstancial estabelecido na atual Constituição Brasileira veda emendas constitucionais na vigência de intervenção federal, de estado de defesa ou de estado de sítio (AFONSO DA SILVA. 2002, p. 66).
} 
Para o presente trabalho mostram-se relevantes as limitações materiais ${ }^{4}$, que se traduzem num conjunto de normas que não podem ser objeto de incidência do poder constituinte derivado, formando um núcleo imodificável da Constituição Federal.

$\mathrm{Na}$ Constituição Federal Brasileira de 1988, as limitações materiais explícitas

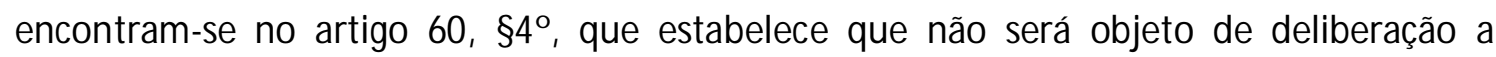
proposta de emenda tendente a abolir: a forma federativa de Estado; o voto direto, secreto, universal e periódico; a separação dos Poderes; e os direitos e garantias individuais.

Assim, caso uma Emenda Constitucional atinja alguma dessas matérias, "padecerá de vício de inconstitucionalidade [...] material [...] e assim ficará sujeita ao controle de constitucionalidade pelo Judiciário" (AFONSO DA SILVA, 2002, p. 68).

Sobre o tema, ensina José Afonso da Silva que:

A vedação atinge a pretensão de modificar qualquer elemento conceitual da Federação ou do voto direto ou indiretamente restringir [...] direito ou garantia individual; basta que a proposta de emenda se encaminhe ainda que remotamente, 'tenda' (emendas 'tendentes', diz o texto) para sua abolição (AFONSO DA SILVA, 2002, p. 67).

Com 0 advento do instituto da repercussão geral no Direito brasileiro (com a Emenda Constitucional no 45/04 e a Lei 11.418/06), iniciou-se discussão sobre se a exigência de demonstração de relevância e transcendência da questão debatida no recurso extraordinário não representaria uma afronta ao princípio constitucional do acesso à justiça,

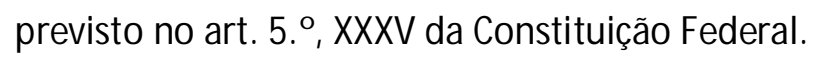

Este princípio constitui-se em um direito fundamental constitucionalmente protegido pelo artigo 60, §4ํำ da CF (limitações materiais explícitas) que prevê, dentre seus incisos, que não será objeto de deliberação a proposta de emenda tendente a abolir os direitos e garantias individuais. Dentro do rol de direitos e garantias individuais, encontra-se 0 direito de acesso à justiça (inciso XXXV do art. 5ํ), razão pela qual eventual norma que 0 ofenda estará eivada de manifesta inconstitucionalidade.

\footnotetext{
${ }^{4}$ Conforme ensina José Afonso da Silva $(2002$, p. 66) as limitações materiais dividem-se em implícitas e explícitas. As limitações materiais explícitas traduzem-se naquelas normas constitucionais que excluem, de forma expressa, determinadas matérias da esfera de atuação do poder reformador. Já as limitações materiais implícitas são aquelas que decorrem da lógica, ou seja, estão relacionadas com aquelas normas que se pudessem ser alteradas, tornariam as limitações explícitas inócuas. Nesse sentido, considera-se uma limitação material implícita a proibição de alteração das normas relativas ao processo de emenda constitucional.
} 
Assim, a questão que se busca elucidar no presente trabalho versa sobre possível inconstitucionalidade do instituto da repercussão geral por afronta ao direito fundamental de acesso à justiça.

0 princípio fundamental do acesso à justiça

A jurisdição se impõe, via de regra ${ }^{5}$, como uma atividade exclusiva do Poder Judiciário para solucionar os conflitos da sociedade. Portanto, cabe ao Estado resolver esses conflitos, sendo vedado ao cidadão solucioná-los por conta própria (GERAIGE NETO, 2003, p. 12).

Nesse sentido, leciona Araken de Assis que:

Ao proibir os cidadãos de resolverem por si suas contendas, o Estado avocou 0 poder de resolver os conflitos de interesses, inerentes à vida social, e, correlatamente, adquiriu o dever de prestar certo serviço público, que é a 'jurisdição'. Aos interessados nessa atividade o Estado reconhece 0 direito de provocá-la, preventiva ou repressivamente (art. 5.․, XXXV, da CF/88) (ASSIS, 1999, p. 9).

A partir do momento em que o Estado tomou para si a obrigação de solucionar os conflitos sociais "ele também assumiu o grave dever de prestar aos cidadãos aquilo que denominamos de adequada tutela jurisdicional" (M ARINONI; ARENHART, 2004, p. 72). Ou seja, ao proibir aos cidadãos que resolvam por conta própria seus conflitos, o Estado deve garantir que estes cidadãos tenham acesso a um órgão estatal apto a resolvê-los. Nesse sentido, cabe à função jurisdicional o "importante papel de fazer valer o ordenamento jurídico, de forma coativa, toda vez que seu cumprimento não se dê sem resistência" (BASTOS; M ARTINS, 1989, p. 169).

Sobre o tema, leciona Humberto Theodoro Júnior:

Num Estado de Direito, onde o princípio da legalidade comanda toda a convivência social organizada, é evidente a importância e o relevo da garantia constitucional do direito de estar em juízo para defender-se de agressões ou ameaças a qualquer direito subjetivo, seja contra particular, seja contra o Poder Público. Mesmo porque

\footnotetext{
${ }^{5}$ A jurisdição é atividade típica do Poder Judiciário. Contudo, há órgãos que estão fora do Poder Judiciário e que exercem atipicamente essa função, como, por exemplo, o Poder Legislativo quando procede ao julgamento de impeachment, e o Poder Executivo, ao exercer a jurisdição administrativa (TAVARES, 2003, p. 499).
} 
o Estado assumiu, de forma definitiva, o monopólio da Justiça e proibiu a solução dos litígios pela força privada dos próprios litigantes (THEODORO JÚNIOR, 1997, p. 46).

Muito embora Pontes de Miranda (apud BASTOS, 1998, p. 213) aponte que 0 princípio do acesso à justiça já existia de forma implícita no Direito Brasileiro desde a Constituição de $1891^{6}$, é certo que o dito princípio somente surgiu de forma expressa com a Constituição de 1946, que dizia que "a lei não poderá excluir da apreciação do Poder Judiciário qualquer lesão de direito individual"7 (GERAIGE NETO, 2003, p. 33).

Na atual Constituição esse dever do Estado (e direito do cidadão), encontra previsão no inciso XXXV do artigo 5. que estabelece que "nenhuma lei excluirá da apreciação do Poder Judiciário lesão ou ameaça a direito". Instituiu-se, assim, o princípio constitucional garantidor do acesso à justiça, também denominado princípio da inafastabilidade do controle jurisdicional, princípio da ubiqüidade, princípio da indeclinibilidade da Jurisdição, princípio de acesso ao Judiciário ou, simplesmente, princípio do acesso à justiça (LEITE, 2007, p. 56).

Esse princípio fundamental garante a todas as pessoas o direito de acesso ao Poder Judiciário. Ou seja, garante o direito de ação, que deve ser compreendido como o direito de se buscar o Judiciário para a obtenção de uma decisão (ALVIM , 2001, p. 189).

Pode-se dizer que 0 inciso XXXV do artigo 5. da CF, constitui-se em uma garantia ${ }^{8}$ constitucional, cujo objetivo é tornar efetivo o direito de ação. Ou seja, é uma garantia que "dirige-se diretamente ao legislador, que não pode pretender, por meio de lei, delimitar o âmbito de atividade do Poder Judiciário" (TAVARES, 2003, p. 498).

Portanto, o destinatário principal desta norma é o legislador, contudo, "o comando constitucional atinge a todos indistintamente, vale dizer, não pode o legislador e ninguém mais impedir que o jurisdicionado vá a juízo deduzir pretensão" (NERY JUNIOR, 2004, p. 130).

\footnotetext{
${ }^{6}$ Data em que o Brasil se filiou à tripartição de Poderes, que previa o Poder Judiciário como recurso a se buscar quando da violação de um direito (BASTOS, 1998, p. 213).

${ }^{7}$ Note-se que a Constituição Federal de 1946 previa tão somente a tutela reparatória (não prevendo a tutela preventiva, como faz a atual Constituição).

${ }^{8}$ Haja vista que limita o poder do legislador ordinário, proibindo-o de produzir leis que limitem o acesso ao Poder Judiciário.
} 
Por tratar-se de direito fundamental ${ }^{9}$, o direito de ação submete-se à Teoria dos Direitos Fundamentais. Pode-se concluir, portanto, que, quanto a sua estrutura, ele se constitui em um princípio constitucional, com alto grau de generalidade e abstração e que sempre deverá ser aplicado na maior medida possível (BARROSO, 2003, p. 26).

Sobre o direito de ação, leciona Arruda Alvim que:

No plano jurídico-constitucional, onde originária e primariamente se situa a ação, consubstancia-se ela num direito autônomo e absolutamente abstrato, consistente no direito que tem 0 indivíduo de pedir tutela jurisdicional ao Estado, relativamente a uma pretensão, podendo dessa ação, ao nível constitucional, nascer a ação do processo civil. Vincula-se ao direito de ação o indeclinável dever de prestação jurisdicional; conseqüentemente constituem-se - uma e outra - em verdadeiras condições de funcionamento e eficiência de um ordenamento jurídico, desde que ocorrentes conflitos de interesses, traduzidos em lide e levados ao Judiciário para solução (ARRUDA ALVIM, 2001, p. 190).

Grande parte da doutrina assevera que o acesso à justiça não se resume ao direito à simples tutela jurisdicional. Para esses doutrinadores, o direito de acesso à justiça seria mais amplo, conferindo ao jurisdicionado o direito à tutela adequada, efetiva e tempestiva.

Diz-se que há tutela adequada quando há previsão de procedimento hábil para atender determinada situação concreta, como, por exemplo, a previsão de tutelas de urgência. Ademais, se faz necessário que a tutela seja efetiva, ou seja, ela precisa ser apta a realizar concretamente os direitos. Por fim, esta tutela precisa ser tempestiva, ou seja, deve ser concedida dentro de um prazo razoável (M ARINONI; ARENHART, 2004, p. 72).

Nesse sentido, conceituando 0 acesso à justiça como um direito mais amplo, Geraige Neto diz que:

[...] o princípio que prevê o direito de ação não pode ser entendido como a 'simples' garantia ao jurisdicionado em poder provocar o Poder Judiciário à salvaguarda de seus

eventuais direitos. Isto é, essa garantia não pode ser interpretada como a mera possibilidade de o cidadão ingressar em juízo, mas, muito mais do que isso, o princípio da inafastabilidade do controle jurisdicional visa a garantir ao jurisdicionado um processo célere com a devida segurança, e efetivo com a necessária justiça, norteado à luz do 'due process of law' e, por conseguinte, dos princípios da isonomia, do juiz e do promotor natural, do contraditório e ampla defesa, da proibição da prova ilícita, da motivação das decisões judiciais, do duplo

\footnotetext{
${ }^{9} \mathrm{O}$ direito de ação constitui-se em direito fundamental tanto material como formalmente, pois se encontra positivado na Constituição Federal (aspecto formal), bem como seu conteúdo é de extrema relevância para o ordenamento jurídico (aspecto material).
} 
grau de jurisdição [...] e outros. [...] oferecer ao jurisdicionado a mera possibilidade de ingressar em juízo não significa dar cumprimento ao princípio da inafastabilidade do controle jurisdicional (GERAIGE NETO, 2003, p. 29).

Também para Nelson Nery Junior:

Pelo princípio constitucional do direito de ação, todos têm o direito de obter do Poder Judiciário a tutela jurisdicional adequada. Não é suficiente o direito à tutela jurisdicional. É preciso que essa tutela seja a adequada, sem o que estaria vazio de sentido o princípio (NERY JUNIOR, 2004, p. 132).

Quanto a necessidade de ser a tutela jurisdicional tempestiva, é essencial que existam mecanismos processuais que garantam ao jurisdicionado a proteção efetiva ao seu direito dentro de um prazo razoável (RODRIGUES, 2005, p. 284).

Sobre esta relação do princípio do acesso à justiça com a duração razoável do processo, cabe a observação de que princípio da celeridade processual, também chamado de princípio da razoável duração do processo, foi introduzido de forma expressa no ordenamento pátrio pela Emenda Constitucional № 45. Dentre as várias modificações trazidas pela Emenda, houve a inserção do inciso LXXVIII ao artigo 5o da Constituição Federal, alargando o rol de direitos e garantias individuais. Este inciso assegura a razoável duração do processo e os meios para garantir a celeridade de sua tramitação, inserindo, assim, o princípio da razoável duração do processo ao ordenamento jurídico brasileiro de forma expressa (TAVARES, 2005).

Mesmo antes de se colocar este princípio de forma expressa no texto constitucional, sua existência já era reconhecida como uma decorrência do próprio princípio do acesso à justiça ${ }^{10}$ no seu conceito mais amplo. Sobre o tema:

A obrigatoriedade da prestação jurisdicional em um prazo razoável deriva, em primeiro lugar, do princípio da inafastabilidade do Poder Judiciário [...]. Com a proibição da autotutela por parte do indivíduo, assumiu o Estado a responsabilidade pela adequada solução dos conflitos de interesses. Nesse sentido, essa garantia refere-se não apenas ao acesso à justiça, mas ao adequado acesso à justiça. Nesse contexto, implícita a exigência de que a prestação jurisdicional ocorra em um prazo razoável e que existam os meios necessários à sua efetivação (RODRIGUES, 2005, p. 287).

\footnotetext{
${ }^{10}$ Ademais, mesmo antes da EC no 45, o fato de o Brasil ter aderido em 1992 à Convenção Americana de Direitos Humanos (Pacto de San José da Costa Rica), que prevê expressamente que toda pessoa tem o direito de ser ouvida em um prazo razoável, já tornava obrigatória a observância da celeridade processual (RODRIGUES, 2005, p. 287)
} 
Esse princípio exige que a justiça solucione as controvérsias de forma breve e eficaz (SCARTEZINI, 2005, p. 43). Todavia, cabe o alerta de que "não se busca a celeridade da prestação jurisdicional a qualquer curso, o que se pretende é um processo em que sejam respeitadas todas as garantias, porém, sem dilações indevidas e inoportunas" (NOTARIANO JUNIOR, 2005, p. 61).

Da compatibilidade do instituto da repercussão geral e do direito fundamental de acesso à justiça

M otivos da criação do instituto: A crise do Supremo Tribunal Federal

O Supremo Tribunal Federal constitui-se na cúpula ${ }^{11}$ do Poder Judiciário do Brasil, possuindo competência nacional, tanto na esfera federal quando na esfera estadual (AGRA, 2002, p. 460).

Dentre as competências conferidas ao Supremo Tribunal Federal no artigo 102 da Constituição Federal, tem-se que sua principal função é a de guarda da Constituição. Sobre o tema, coloca Nelson Nery Júnior que:

No atual sistema constitucional brasileiro, temos realmente uma Corte Constitucional federal, consubstanciada no STF [...] Ao STF coube, com exclusividade, a importantíssima tarefa de dizer a palavra definitiva sobre a interpretação do texto constitucional (NERY JUNIOR, 2004, p. 29).

Se por um lado a Constituição Federal de 1988 tornou o STF uma corte quase que exclusivamente Constitucional ${ }^{12}$, por outro, esta mesma Constituição ampliou consideravelmente o rol de matérias constitucionais, fazendo com que um grande número de processos fossem levados ao STF (LAMY, 2005, p. 173).

${ }^{11}$ No sentido de que o STF chefia funcionalmente o Poder Judiciário, muito embora não o faça administrativamente (FERREIRA FILHO, 2003, p. 264).

12 Para Uadi Lammêgo Bulos (2003, p. 957) o Supremo Tribunal Federal não seria rigorosamente uma Corte Constitucional. Isso porque, muito embora a ele compita, precipuamente, a guarda da Constituição, ele não é o único órgão competente para compor litígios constitucionais, haja vista que o ordenamento jurídico brasileiro admite o controle difuso de constitucionalidade. 
Não fosse isso suficiente, o STF acumula, além da função de Tribunal Constitucional, as funções de tribunal comum de última instância e de instância comum originária para causas não constitucionais ${ }^{13}$.

Essa grande carga de processos, levou o Pretório Excelso a um momento de crise, onde ele não mais estava sendo capaz de absorver a quantidade de processos e recursos que chegavam a ele (TAVARES, 2005, p. 89).

Mesmo com a criação do STJ e retirando da esfera do STF a competência para guardar 0 texto federal, os dados indicam que em 1997 (quase 10 anos após 0 início da vigência da Carta de 1988) o STF recebeu 42.000 processos, ao passo que a Suprema Corte americana, recebeu no período de 1996, 366 processos, acolhendo apenas 126 para apreciar; já a corte alemã, ao receber 3.000 processos, pinçou apenas trezentos e poucos para decidir (SARTÓRIO; JORGE, 2005, p. 184).

A partir desse panorama questionou-se se não seria benéfica a instituição de um mecanismo de filtragem que permitisse ao STF selecionar as causas onde sua atuação efetivamente vá auxiliar na guarda e defesa da Magna Carta. Sobre o tema, indagam Marinoni e Mitidiero:

Como deve o Supremo Tribunal Federal desempenhar essa sua função? Examinando todas as questões que lhe são apresentadas ou apenas aquelas que Ihe pareceram de maior impacto para obtenção da unidade do Direito? 0 pensamento jurídico contemporâneo inclina-se firmemente nesse segundo sentido. A simples intenção da justiça quanto à decisão do caso concreto - e, com ela, também o interesse das partes na causa, por si só não justifica a abertura de uma terceira (e, eventualmente, quarta) instância judiciária. 0 que fundamente, iniludivelmente, é o interesse na concreção da unidade do Direito [...] Daí a oportunidade e 0 inteiro acerto de instituir-se a repercussão geral da controvérsia constitucional afirmada no recurso extraordinário como requisito de admissibilidade desse (M ARINONI; MITIDIERO, 2007, p. 17).

Também José Rogério Cruz e Tucci (2007, p. 24) entende que foi "considerando a necessidade de diminuir o número e, ao mesmo tempo, de acelerar a marcha dos recursos nos tribunais superiores" que a EC no 45 introduziu o instituto da repercussão geral.

\footnotetext{
${ }^{13} \mathrm{O}$ artigo 102 da Constituição Federal prevê ao STF competência originária e recursal, sendo que esta última se divide em ordinária e extraordinária. Conforme ensina Nelson Nery Junior, a competência originária e a competência recursal ordinária "nada têm a ver com a incidência ou interpretação direta das normas constitucionais, mas sim com a manutenção da ordem constitucional pelo seu intérprete maior" (NERY JUNIOR, 2004, p. 32).
} 
Deve-se levar em conta que muitas questões que atualmente são levadas ao STF têm repercussão limitada às partes, ou a pequeno número de casos. Havendo ainda, situações cujas "conseqüências são muito reduzidas, mesmo para as partes, servindo antes como pretexto para manobras protelatórias ou que visam a subtrair o mérito do litígio ao direito aplicável" (GERAIGE NETO, 2003, p. 110).

Assim, pode-se dizer que a exigência de repercussão geral nos recursos extraordinários potencializará o importante papel do STF no ordenamento jurídico, dispensando-o de pronunciar-se sobre assuntos rotineiros, onde este pronunciamento não se justifica, principalmente porque acarretaria em um imenso trabalho, que prejudica 0 julgamento de casos importantes (ALVIM, 2005, p. 83).

Nesse sentido, coloca Arruma Alvim:

[...] o STF, se delimitada a sua função ao exame das questões constitucionais, por ele havidas como representativas de repercussão geral [...] virá a desempenhar mais acuradamente a sua função de tribunal de cúpula, de toda a Justiça brasileira, no que diz respeito à sua competência constitucional. [...] a repercussão geral é um sistema de filtro que permite afastar do âmbito dos trabalhos do tribunal as causas que não têm efetivamente maior importância e cujo pronunciamento do tribunal é injustificável (ALVIM, 2005, p. 86).

Portanto, muito embora o instituto da repercussão geral tenha sido introduzido em razão da sobrecarga atual que vivencia o STF, sua instituição se justifica amplamente "seja pela posição do STF, seja, ainda, pela própria ausência de razão de ser para o julgamento indiscriminado de todos os recursos extraordinários suscetíveis de serem interpostos, com alegação de lesão à Constituição" (ALVIM , 2005, p. 89).

Sobre o tema coloca Eduardo Cambi:

[...] o critério a transcendência não deve ser visto apenas como uma técnica de auto-contenção judicial, restringindo o acesso ao STF [...], com a simples proposta de diminuição de sua carga de trabalho, mas uma oportunidade de visualização de uma clara válvula de abertura do sistema recursal, para que a Suprema Corte contribua, de modo mais efetivo, para com a melhor distribuição da justiça, abrindo maior espaço em sua agenda para a tutela dos direitos fundamentais e para o desenvolvimento do Estado de Direito Democrático brasileiro (CAM BI, 2005, p. 161).

Assim, conforme coloca Arruda Alvim (2005, p. 89), pode-se concluir que a repercussão geral virá a ser um "meio apto a resolver a crise do STF, ao lado do que 
proporcionará condições próximas das ideais para o alto desempenho dessa Corte de Justiça, cujas decisões devem ser sempre modelos e paradigmas para a Nação".

\section{Da constitucionalidade do instituto da repercussão geral}

Cabe agora analisar a seguinte questão: "constituir-se-ia em efetiva negação de acesso à Justiça discriminarem-se determinadas demandas, que, por não serem relevantes ou não carregadas de repercussão geral, não chegariam ao STF?" (ALVIM , 2005, p. 85)

Conforme dito anteriormente, o direito de ação, consiste no "direito de acessar o Estado-juiz [...] para dele cobrar o fornecimento de uma decisão que componha um certo conflito de interesses" (CONRADO, 2003, p. 161). Com vista a esse conceito, pode-se dizer que o princípio do acesso à justiça, em seu sentido mais restrito, visa garantir é tão somente a obtenção da tutela jurisdicional, e não o acesso interminável e sem limites a todos os órgãos do Poder Judiciário. Nesse sentido, leciona Nelson Nery Júnior que:

A realização de um direito subjetivo é alcançada quando se consegue o objeto desse mesmo direito. Como o objeto do direito subjetivo de ação é a obtenção da tutela jurisdicional do Estado, deve entender-se por realizado o direito subjetivo de ação assim que pronunciada a sentença, favorável ou não ao autor (NERY JUNIOR, 2004, p. 137).

Buscando realizar o acesso à justiça, existe no Brasil toda uma estrutura judiciária que atua sobre todo o território nacional e que se divide nas diversas Justiças Estaduais, na Justiça Federal e nas Justiças especializadas, todas elas possuindo um amplo sistema recursal. Ademais, culmina a Justiça Civil, ainda, com um amplo acesso ao ST], haja vista que para este órgão não se instituiu a exigência de repercussão geral (ALVIM , 2005, p. 85).

Em complementação a esse pensamento, coloca Arruda Alvim que:

Esses aparelhos judiciários desdobram-se em dois graus de jurisdição, exercidos com apreciável plenitude a começar ou até porque cabem recursos de todas as interlocutórias. Desta forma, há plena garantia de acesso à Justiça, e, de mais a mais, nem se compreenderia que a função do STF fosse a de completar o acesso à Justiça em todas as causas, em todos os incidentes, em que esteja envolvida matéria constitucional, justamente porque este tribunal deve existir para resolver qualificadamente as questões constitucionais que sejam relevantes ou fundamentais, tendo em vista a inteligência do direito constitucional (ARRUDA ALVIM, 2005, p. 85). 
Portanto, obtida a tutela jurisdicional do Estado teremos que o direito subjetivo de ação já foi realizado. A possibilidade de acesso ao recurso extraordinário, não visa permitir a realização do acesso à justiça (que já foi realizado com a decisão de primeiro grau). Seu objetivo não é o mero reexame da matéria e sim "garantir a observância da Constituição [...], verificando o Tribunal se na sentença recorrida foi corretamente aplicada [...], quer quanto à norma invocada quer quanto à interpretação que Ihe foi dada" (CAETANO, 1987, p. 463). É nesse sentido que André Ramos Tavares diz que:

[...] a preocupação no julgamento desses recursos não é com eventual injustiça praticada em decisão anterior, mas sim com o Direito objetivamente considerado. [...] A situação individual apresentada no recurso é também resolvida, contudo, como decorrência lógica da manutenção da integridade do Direito e da Constituição federais. É por isso correto afirmar que não basta, para o exercício dos recursos excepcionais, a sucumbência da parte. É a questão federal e a constitucional que ensejarão o cabimento dos recursos (TAVARES, 2003, p. 297).

Assim, com a obtenção da tutela jurisdicional do Estado, teremos que o direito subjetivo de ação já foi realizado, sendo que obstar a interposição do recurso extraordinário ao STF não fere esse direito. Ou seja, a decisão proferida na instância anterior já é suficiente para efetivar o direito de ação, principalmente porque todos os órgãos do Poder Judiciário têm competência para analisar matéria constitucional via controle difuso, o que impossibilita 0 argumento de que somente o STF poderia satisfazer a pretensão do recorrente.

Sempre foi pacífico na doutrina que, para a interposição dos recursos excepcionais não basta a mera sucumbência da parte, fato que impossibilita que consideremos esses recursos como recursos de terceiro grau de jurisdição. Sempre foi necessário que se comprovasse 0 enquadramento em alguma das condições constitucionalmente exigidas, ou seja, o recurso excepcional precisava objetivar a defesa da Constituição (no caso do recurso extraordinário) ou da unidade do Direito federal (no caso do recurso especial). Isso significa que sempre se admitiu restrição constitucional para 0 acesso a essas instâncias, haja vista que essa restrição está intimamente ligada à função destes recursos e à função desses tribunais (TAVARES, 2003, p. 297).

Conforme dito anteriormente, com a obtenção da tutela jurisdicional por meio da decisão judicial de primeiro ou segundo grau, tem-se que o acesso à justiça já esta realizado. Esta idéia está relacionada com o conceito mais restrito de acesso à justiça. Contudo, mesmo 
para os que não aceitam este aspecto meramente formal do acesso à justiça, dizendo que a prestação jurisdicional, para realizar este princípio, deve se dar de forma adequada, efetiva e tempestiva, não cabe o argumento de que a exigência de repercussão geral representa limitação ao acesso à justiça. Ora, sob esse aspecto mais amplo, a exigência da repercussão geral, ao impedir que se prolongue no tempo o julgamento de processo onde 0 pronunciamento do STF é irrelevante, está realizando a idéia de tutela jurisdicional adequada, efetiva e tempestiva, especialmente quanto ao aspecto da tempestividade.

Conforme dito anteriormente, deflui do próprio conceito de acesso à justiça a idéia de que a prestação jurisdicional precisa se dar dentro de um prazo razoável, haja vista que "se o Estado tem o monopólio da jurisdição, deve exercê-lo com eficiência" (VARGAS, 2005, p. 344).

Essa exigência, atualmente, encontra-se expressa no inciso LXXVIII do artigo 50 da Constituição Federal que consagra o princípio da celeridade processual, direito fundamental introduzido pela Emenda Constitucional no 45.

0 princípio da celeridade processual (e, indiretamente, o próprio princípio do acesso à justiça) impõe que a tutela jurisdicional se dê dentro de um lapso temporal razoável. Nesse sentido, colocam Bielsa e Graña:

Um julgamento tardio irá perdendo progressivamente seu sentido reparador, na medida em que se postergue o momento do reconhecimento judicial dos direitos. E, transcorrido o tempo razoável para resolver a causa, qualquer solução será, de modo inexorável, injusta, por maior que seja o mérito científico do conteúdo da decisão (BIELSA; GRAÑA apud RODRIGUES, 2005, p. 285).

Assim, com o objetivo de viabilizar o direito fundamental da celeridade, bem como de resguardar a função do STF, a EC no 45 introduziu o instituto da repercussão geral. Nesse sentido, coloca André Ramos Tavares que:

Na parte da reforma que se poderia considerar 'estrutural' quanto à celeridade [...], introduzem-se algumas novidades dignas de nota [...]: (i) a busca da redução no número de processos pela redução do número de recursos extraordinários a serem conhecidos (art. 102, § 4으, pelo qual se estabelece, para o recurso extraordinário, a necessidade do recorrente demonstrar 'repercussão geral das questões constitucionais discutidas no caso'); [...] (TAVARES, 2005, p. 33). 
Ora, é incompatível com o princípio da celeridade processual e, conseqüentemente, com o princípio do acesso à justiça, possibilitar que em qualquer assunto relacionado à Constituição, por mais irrelevante que seja, possa a parte interpor recurso extraordinário. Isto acarretaria um grande atraso na prestação da tutela jurisdicional em uma situação onde o recurso extraordinário é incabível, haja vista que a função deste recurso não é satisfazer 0 interesse individual da parte recorrente e sim proteger a norma constitucional. Nesse sentido estabelece Eduardo Cambi que:

A mera previsão formal do recurso extraordinário e a submissão do recorrente a um longo tempo para o seu julgamento é uma forma de negar o acesso à justiça, contribuindo para o descrédito do Poder Judiciário, além de violar, 0 agora explícito direito fundamental, a celeridade da prestação jurisdicional (CAMBI, 2005, p. 158).

Ante 0 exposto, é incabível 0 argumento de que a introdução do instituto da repercussão geral acarretou violação de cláusula pétrea (no caso, o direito individual de ação). As limitações materiais impostas pelo poder constituinte originário visam impedir Emenda Constitucional que pretenda "restringir [...] direito ou garantia individual" (AFONSO DA SILVA, 2002, p. 67), sendo que a EC № 45, por meio da instituição da repercussão geral, não restringiu o direito do acesso à justiça, pelo contrário, introduziu um mecanismo que visa garantir que a tutela jurisdicional do Estado ocorra de forma tempestiva, algo que 0 próprio acesso à justiça exige. Nesse sentido pode se dizer que:

0 processo não apenas deve se preocupar em garantir a satisfação jurídica das partes, mas principalmente, para que essa resposta aos jurisdicionados seja justa, é imprescindível que se faça em um espaço de tempo compatível com a natureza do objeto litigado. Do contrário, torna-se utópica a tutela jurisdicional de qualquer direito [...]. Vencida a etapa de acesso ao Poder Judiciário, resta o não-acesso pela denegação de justiça, entendida como a ausência de mecanismos processuais capazes de garantir uma prestação jurisdicional efetiva - e ela só é efetiva quando o tempo para sua efetivação é compatível com o objeto e os objetivos da demanda (RODRIGUES, 2005, p. 285).

Assim, conclui-se que o instituto da repercussão geral foi introduzido no ordenamento jurídico em sintonia com o princípio da celeridade processual e, conseqüentemente, com o princípio do acesso à justiça. É nesse sentido que se diz que a "efetividade do acesso à justiça passa [...] necessariamente pela existência de instrumentos 
processuais acessíveis e céleres na resolução dos conflitos de interesses que são levados ao Judiciário" (RODRIGUES, 2005, p. 286).

Mesmo se assim não fosse, ou seja, mesmo que se tome como correto (muito embora não o seja pelos motivos acima postos) o argumento de que o instituto da repercussão geral efetivamente representa uma afronta ao princípio do acesso à justiça, ainda assim, teríamos que esse instituto é plenamente constitucional. Isto porque, por tratar-se de um princípio, ele não é absoluto, e, portanto, encontra limites nos demais princípios, ou seja, nos demais valores protegidos pela Constituição, e, dentre eles, o princípio da celeridade do processo.

Conforme coloca a Teoria dos Direitos Fundamentais, os princípios, ao contrário das regras, são relativos. Nenhum deles pode ser aplicado de forma plena e ilimitada, sendo que todo princípio sempre encontra limitação nos demais princípios. Isto também ocorre com 0 princípio do acesso à justiça.

Nesse sentido, ensina Agra que não se deve encarar o acesso à justiça de forma peremptória e irrestrita. "O poder público pode estipular limites na abrangência da esfera recursal, como forma de impedir atos procrastinatórios e proteger a prestação jurisdicional" (AGRA, 2002, p. 183).

É em razão dessa característica que havendo situação de conflito entre dois princípios, será necessária a compatibilização entre eles. Ou seja, admite-se que em determinada situação de conflito se privilegie um dos princípios sem, contudo, afastar o outro completamente (GUERRA FILHO, 2003, p. 58).

Assim, mesmo que se considerasse que o instituto da repercussão geral afronta em certa medida 0 acesso à justiça, ele é aceitável por visar realizar o princípio da celeridade processual, sem, contudo, violar o núcleo essencial do princípio da inafastabilidade da jurisdição.

Nesse sentido, coloca Guerra Filho que "não há princípio do qual se possa pretender seja acatado de forma absoluta, em toda e qualquer hipótese, pois uma tal obediência unilateral e irrestrita a uma determinada pauta valorativa [...] termina por infringir uma outra [...]" (GUERRA FILHO, 2003, p. 46).

Tendo em vista que nenhum princípio é absoluto, bem como que a reforma constitucional não violou cláusula pétrea, temos que é preciso conciliar o instituto da 
repercussão geral com o texto constitucional. Conforme coloca Garaige Neto, "uma vez corretamente introduzido no sistema constitucional [...] a argüição de relevância e o princípio da inafastabilidade do controle jurisdicional [...] deverão ser harmonizados e compatibilizados entre si“ (GERAIGE NETO, 2003, p. 114).

Portanto, tem-se que o instituto da Repercussão Geral está em absoluta harmonia com 0 direito fundamental à tutela jurisdicional efetiva, bem como com 0 direito fundamental à duração razoável do processo. Isso porque as partes somente terão que aguardar as delongas inerentes à tramitação do recurso extraordinário quando seu conhecimento pelo STF for necessário para a realização da unidade do Direito no Estado Constitucional brasileiro (M ARINONI; M ITIDIERO, 2007, p. 17).

\section{Conclusão}

Em razão do grande número de processos que sobrecarregavam o Pretório Excelso (a chamada "crise do Supremo Tribunal Federal") a Reforma do Judiciário (EC no 45/2004) criou 0 instituto da Repercussão Geral, cujo objetivo é o de limitar o número de recursos extraordinários que chegam ao Supremo Tribunal Federal através da exigência de demonstração da repercussão geral da questão constitucional sobre a qual o recurso versa.

Com o surgimento desse novo instituto questionou-se sua constitucionalidade ante possível violação ao direito fundamental do acesso à justiça. Isto porque caso não fosse demonstrada a repercussão geral da questão debatida no recurso extraordinário o jurisdicionado não teria acesso ao Supremo Tribunal Federal para análise do mérito de seu recurso.

Ocorre que o direito fundamental do acesso à justiça, ao assegurar ao jurisdicionado o acesso ao Poder Judiciário em caso de lesão ou ameaça à direito, não inclui 0 acesso a todos os órgãos do Poder Judiciário. Tem-se que 0 acesso à justiça estará plenamente realizado com a prolação da sentença, ou seja, com a tutela adequada, efetiva e tempestiva ao seu pleito e não com a confirmação dessa sentença por todos os órgãos que compõe o Judiciário brasileiro.

Para a realização do acesso à justiça existe uma complexa estrutura judiciária que se desdobra em dois graus de jurisdição. 0 Supremo Tribunal Federal encontra-se acima dessa estrutura e seu objetivo não é realizar o acesso à justiça, pelo menos não diretamente. Sua 
atuação visa garantir a observância das normas constitucionais, razão pela qual impor critérios para as causas que chegam a esse órgão não caracteriza violação ao princípio do acesso à justiça. Pelo contrário, garantir que somente as causas constitucionalmente relevantes cheguem ao STF possibilita que o STF exerça sua função com maior eficiência.

Conforme dito anteriormente, a tutela conferida pelo Poder Judiciário precisa ser, além de adequada e efetiva, tempestiva. Ora, permitir que um processo se prolongue no tempo em um recurso extraordinário, sem que para tanto a tese nele ventilada seja relevante o suficiente para submetê-lo ao crivo do Supremo Tribunal Federal (STF) estaria, em verdade, ferindo o acesso à justiça.

Ademais, o direito fundamental constitui-se em um princípio constitucional e, como tal, encontra limite para sua aplicação nos demais princípios constitucionais. Nesse sentido, mesmo ao se considerar que o instituto da Repercussão Geral ofenda em um grau mínimo o acesso à justiça, sua introdução no ordenamento Constitucional não é inconstitucional, haja vista que ele realiza o princípio da razoável duração do processo, sem restringir o núcleo mínimo do acesso à justiça, gerando um equilíbrio entre esses dois princípios.

Portanto, incabível é o argumento de que o instituto da Repercussão Geral no Recurso Extraordinário seria inconstitucional por violação ao acesso à justiça. Ao contrário, a introdução desse novel instituto ao ordenamento jurídico brasileiro veio tornar mais efetiva e célere a tutela jurisdicional, bem como reafirmar o importante papel do Supremo Tribunal Federal ao possibilitar que ele se manifeste somente sobre as causas constitucionalmente relevantes.

\section{Referências}

AFONSO DA SILVA, José. Curso de direito constitucional positivo. 20. ed. São Paulo: Malheiros, 2002.

AGRA, Walder de M oura. M anual de direito constitucional. 1. ed. São Paulo: Revista dos Tribunais, 2002.

ALVIM, Arruda. A EC n. 45 e o instituto da Repercussão Geral. In: WAM BIER, Teresa Arruda Alvim et AL. (Coord.). Reforma do Judiciário: primeiras reflexões sobre a Emenda Constitucional n. 45/2004. 1. ed. São Paulo: Editora Revista dos Tribunais, 2005. 
ALVIM , Arruda. Manual de direito processual civil: parte geral. 7. ed. São Paulo: Revista dos Tribunais, 2001.

ASSIS, Araken de. Comentários ao Código de Processo Civil. Rio de Janeiro: Forense, 1999.

BARROSO, Darlan. M anual de direito processual civil: teoria geral e processo de conhecimento. 1. ed. Barueri: Manole, 2003.

BASTOS, Celso Ribeiro; M ARTINS, Ives Gandra. Comentários à Constituição do Brasil: promulgada em 5 de outubro de 1988. 1. ed. São Paulo: Saraiva, 1989.

BASTOS, Celso Ribeiro. Curso de direito constitucional. 19. ed. São Paulo: Saraiva, 1998.

BULOS, Uadi Lammêgo. Constituição Federal anotada. 5. ed. São Paulo: Saraiva, 2003.

CAETANO, M arcello. Direito Constitucional brasileiro. 2. ed. Rio de Janeiro: Forense, 1987.

CAM BI, Eduardo. Critério da transcendência para a admissibilidade do recurso extraordinário (art. 102, § 3.․, da CF): Entre a autocontenção e o ativismo do STF no contexto da legitimação democrática da jurisdição constitucional. In: WAM BIER, Teresa Arruda Alvim et AL. (Coord.). Reforma do Judiciário: primeiras reflexões sobre a Emenda Constitucional $n$. 45/2004. 1. ed. São Paulo: Editora Revista dos Tribunais, 2005.

CONRADO, Paulo César. Introdução à teoria geral do processo civil. 2. ed. São Paulo: Max Limonad, 2003.

FERREIRA FILHO, M anoel Gonçalves. Curso de direito constitucional. 30. ed. São Paulo: Saraiva, 2003.

GERAIGE NETO, Zaiden. 0 princípio da inafastabilidade do controle jurisdicional: art. 50, inciso XXXV da Constituição Federal. 1. ed. São Paulo: Editora Revista dos Tribunais, 2003.

GUERRA FILHO, Willis Santiago. Processo Constitucional e direitos fundamentais. 3. ed. São Paulo: Celso Bastos Editor, 2003.

LAMY, Eduardo de Avelar. Repercussão Geral no Recurso Extraordinário: a volta da Argüição de Relevância? In: WAM BIER, Teresa Arruda Alvim et AL. (Coord.). Reforma do Judiciário: primeiras reflexões sobre a Emenda Constitucional n. 45/2004. 1. ed. São Paulo: Editora Revista dos Tribunais, 2005.

LEITE, Carlos Henrique Bezerra. Curso de direito processual do trabalho. 5. ed. São Paulo: LTr, 2007.

M ARINONI, Luiz Guilherme; M ITIDIERO, Daniel. Repercussão Geral no Recurso Extraordinário. 1. ed. São Paulo: Editora Revista dos Tribunais, 2007. 
MARINONI, Luiz Guilherme; ARENHART, Sérgio Cruz. Manual do processo de conhecimento. 3. ed. São Paulo: Editora Revista dos Tribunais, 2004.

NERY JÚNIOR, Nelson. Princípios do processo civil na Constituição Federal. 8. ed. São Paulo: Editora Revista dos Tribunais, 2004.

NOTARIANO JUNIOR, Antonio de Pádua. Garantia da razoável duração do processo. In: W AM BIER, Teresa Arruda Alvim et AL. (Coord.). Reforma do Judiciário: primeiras reflexões sobre a Emenda Constitucional n. 45/2004. 1. ed. São Paulo: Editora Revista dos Tribunais, 2005.

RODRIGUES, Horácio Wanderlei. EC n. 45: Acesso à justiça e o prazo razoável na prestação jurisdicional. In: WAMBIER, Teresa Arruda Alvim et AL. (Coord.). Reforma do Judiciário: primeiras reflexões sobre a Emenda Constitucional n. 45/2004. 1. ed. São Paulo: Editora Revista dos Tribunais, 2005.

SARTÓRIO, Elvio Ferreira; JORGE, Flávio Cheim. O Recurso Extraordinário e a demonstração da Repercussão Geral. In: WAM BIER, Teresa Arruda Alvim et al. (Coord.). Reforma do Judiciário: Primeiras reflexões sobre a Emenda Constitucional n. 45/2004. 1. ed. São Paulo: Editora Revista dos Tribunais, 2005.

SCARTEZZINI, Ana M aria Goffi Flaquer. O prazo razoável para a duração dos processos e a responsabilidade do Estado pela demora na outorga da prestação jurisdicional. In: W AM BIER, Teresa Arruda Alvim et al. (Coord.). Reforma do Judiciário: primeiras reflexões sobre a Emenda Constitucional n. 45/2004. 1. ed. São Paulo: Editora Revista dos Tribunais, 2005.

TAVARES, André Ramos. Curso de direito constitucional. 2. ed. São Paulo: Saraiva, 2003.

TAVARES, André Ramos. Reforma do Judiciário no Brasil pós-88. 1. ed. São Paulo: Saraiva, 2005.

THEODORO JÚNIOR, Humberto. Direito e processo: direito processual civil ao vivo. 1. ed. Rio de Janeiro: Aide, 1997.

TUCCI, José Rogério Cruz. Anotações sobre a repercussão geral como pressuposto de admissibilidade do Recurso Extraordinário (Lei n011.418/2006). Revista do Advogado, São Paulo, n. 92, p. 23-31, jul. 2007.

VARGAS, Jorge de Oliveira. A garantia fundamental contra a demora no julgamento dos processos. In: WAM BIER, Teresa Arruda Alvim et al. (Coord.). Reforma do Judiciário: primeiras reflexões sobre a Emenda Constitucional n. 45/2004. 1. ed. São Paulo: Editora Revista dos Tribunais, 2005. 